\section{Out of the frying pan into the goalbox}

\section{LEONA RD BROSGOLE, SONYA K. SOBRIAN, and ANGELO F. CONTINO St. John's University, Jamaica, New York 11432}

Using heat as a negative reinforcer was shown to be highly efficient in producing a discriminative response in Long-Evans rats. Heat failed to generate the emotional responses usually associated with shock as an aversive stimulus. In a separate study, using the heat-training procedure, age differences in the learning facility of Swiss/ICR (Ha) mice were detected.

Ongoing research in our laboratory necessitated the adoption of a rapid method for establishing a discriminative response in a two-choice situation, and the use of electric shock as an aversive stimulus seemed ideal. However, a review of the literature indicated that, although shock has been employed predominantly as a source of negative reinforcement, as well as a motivator, its utilization often imposes limitations which give rise to several artifacts. These include the intrusion of fear responses (Mowrer \& Lamoreaux, 1951), other competing avoidance responses (Wischner, 1947), and possible shock effects on protein synthesis (Barondes \& Cohn, 1968; Agranoff et al, 1967).

Accordingly, we explored the feasibility of utilizing heat as a noxious stimulus in an avoidance learning situation. A relatively low level of thermal stimulation was used to motivate the animal, while a higher intensity served as a negative reinforcer. Heat was applied directly to the paw by means of conducting plates placed upon the floor of a problem box.

\section{EXPERIMENT 1}

In the first experiment, we compared the effects of heat and shock in a brightness discrimination task.

\section{Method}

Subjects. Twenty-four Long-Evans rats between the ages of 7 and 8 months were used. There were 13 females and 11 males. All animals were laboratory bred.

Apparatus. Two training devices were used. The testing box designed to administer heat was $113 / 4$ in. wide $x$ 12 in. deep (front to rear) $\times 81 / 2$ in. high; its two sides and back panel were aluminum and the front was Plexiglas. To facilitate cleaning, the sides of the box were not connected to the floor.

Two Masonite panels were fastened together to form the letter "T." This served as an insert to divide the box into thirds. The start position was in the front portion of the box, which was sectioned off from side to side by the crossbar of the $T$. The remaining leg of the $T$ divided the rear $2 / 3$ section into two symmetrical halves. Hence, when in the start position and facing the rear of the apparatus, the animal viewed a Masonite wall, or front panel, which occluded two goalboxes, one on the left and one on the right. The left half of the front panel was painted flat black, and the right half flat white. A set of swinging doors $\left(3 \frac{1}{2} \times 3 \frac{1 / 4}{4}\right.$. $)$ was cut and mounted to each half of the panel to provide access to both the left and right goalbox. The color of the doors corresponded to the surrounding panel. They were constructed to swing into the goalbox, but not back out tow ard the start position. The interior of both goalboxes was aluminum color. A duplicate set of inserts was constructed, with the exception that the left side of the front panel was flat white, and the right side black. Thus, by interchanging the two inserts throughout the training procedure, position learning was precluded.

The floor of the startbox and two goalboxes consisted of a 1/8-in. galvanized steel plate. There were three plates in all, each being isolated from the other as well as the aluminum walls of the device. Heat was applied to each plate from below by three GE (No. 2A 400), 75-W $115-\mathrm{V}$ ac heating units. The output of each unit was regulated by a rheostat, wired to function as a voltage divider. The surface temperature of the floor in the startbox was calibrated at $35^{\circ} \mathrm{C}$, while the plates in the goalboxes were $45^{\circ} \mathrm{C}$. In order to distinguish between goalboxes, the floor of the positive box was insulated with $1 / 8$-in.-thick Masonite painted aluminum color.

The shock enclosure was 12 in. wide $x 10^{1 / 2}$ in. deep $x 10$ in. high, with aluminum sides, Plexiglas front and back, and a wire grid floor. Scrambled shock was delivered to the grid by means of a Grason-Stadler shock generator, Model E6070B. The shock intensity in the startbox was $1.3-1.6 \mathrm{~mA}$, and in the negative goalbox, $2 \mathrm{~mA}$.

Training. Twelve animals were trained with heat (Group 1) and 12 with electric shock (Group 2). In the first group, 9 Ss were females and 3 males; in the second, 4 were females and 8 males. Black was positive for half the animals in each group and white for the remaining half. The position of the positive goalbox was randomized for each animal, with the proviso that it would not be placed on the same side for more than three consecutive trials, and that it would be divided equally between left and right over each block of 10 trials.

For Group 1, a trial consisted of the animal's being placed in the startbox upon the $35^{\circ} \mathrm{C}$ floor. This temperature seemed mild enough not to be injurious, but intense enough to promote a moderate amount of activity. Committing the correct response enabled the animal to secure refuge upon the insulated floor of thepositive goalbox. The animal was detained in this box for $10 \mathrm{sec}$ before being returned to the startbox for the next trial. However, upon making an incorrect response, the rat entered the negative goalbox with the $45^{\circ} \mathrm{C}$ floor, where it was detained for $10 \mathrm{sec}$, and then returned to the start position for the next trial.

The second group was treated in the same fashion, except that electric shock was administered instead of heat. When in the start position, the animal received $1.3 \mathrm{~mA}$ of shock. Rats unresponsive to this level received $1.6 \mathrm{~mA}$. A correct response led to a $10 \mathrm{sec}$ detention on the neutral grid floor of the positive goalbox. After an incorrect response, the animal entered the negative goal, where it received $2 \mathrm{~mA}$ of shock over a $10 \mathrm{sec}$ interval, delivered in three $1 \mathrm{sec}$ bursts.

Five trials were given per day, because Group 2 would not tolerate more intensive training. The criterion level was set at 10 consecutive errorless trials, or 2 days of perfect performance. These criterion trials are not included in the data.

\section{Results and Discussion}

The heat-trained group required a median number of 20 trials before meeting criterion on the brightness discrimination task. For the group as a whole, learning occurred within 5-40 trials. Group 2 required a median number of 50 trials before reaching criterion. While one animal required only 10 trials prior to achieving errorless performance, two were unable to complete the task. Training was discontinued after 125 trials, or 25 days of testing. The two groups differed significantly according to the Mann-Whitney $U$ test ( $U=24$, $p<.02)$.

Under the circumstances of this particular study, the use of heat as a noxious stimulus seemed preferable to shock in ways other than facilitating learning efficiency. Group 1 animals made very few attempts to escape from the apparatus, and those were 
rather early in training. They tended to respond immediately upon being placed in the startbox, and did not appear adversely affected by the punishment. There were no attempts to attack $E$ upon being removed from the negative goalbox. Animals in Group 2 continually yelped, jumped, urinated, and defecated, and they exhibited a tremendous response latency, even after many days of training. In addition, these Ss hesitated entering the goalbox, even when comitting a correct response.

The data indicate two limitations to heat training: (1) the animal must be kept moving (if permitted to cower or cringe, the foot may become reddened and blistered), and (2) it can be difficult to deliver and terminate the heat instantaneously. Accordingly, our apparatus was turned on $1 / 2 \mathrm{~h}$ prior to testing, and a Masonite pad was used to insulate the floor of the positive goalbox.

In spite of these limitations, heat significantly enhanced learning speed and generated a far more pleasurable testing situation than did shock.

\section{EXPERIMENT 2}

A second study was aimed at determining whether heat training was sensitive enough to detect the effect of age on learning speed (as demonstrated by d'Amato \& Jagodo, 1950; Denenberg, 1958; Liu, 1928; Long \& Evans, 1922; and Yerkes, 1909).

\section{Method}

Four groups of Swiss/ICR (Ha) mice were tested. Groups 1-4 were 40, 70, 106 , and 130 days old, respectively. Three of the age groups consisted of 12 animals each. The remaining group ( 70 days old) had only 8 mice, as some were lost through disease. In each group, half of the animals were males.

The testing apparatus was the same as that used with the heat-trained rats, except that the openings in the front panels were smaller $\left(2^{1 / 2} \times 2^{1 / 4}\right.$ in. $)$ and the swinging doors were replaced with a piece of stiffened leather, hinged at the top, to compensate for the smaller size of the mice.

The training procedure and criterion level were identical to those employed in the first experiment.

\section{Results and Discussion}

Groups 1-4 reached the criterion level in a mean number of $32.1,28.8$, 57.1 , and 54.6 trials. These differences were significant according to a Kruskal-Wallis one-way analysis of variance $(\mathrm{H}=23.8, \mathrm{df}=3, \mathrm{p}<.01)$. Subsequent $U$ tests indicated that Groups 1 and 2 did not differ significantly $(U=37.5)$. Similarly, Groups 3 and 4 were essentially the same $(U=62.5)$. However, Group 1 differed reliably from Group 3 ( $U=5$, $\mathrm{p}<.01)$, as well as Group $4(\mathrm{U}=18.5$, $\mathrm{p}<.01)$. In the same fashion, the 70-day-old animals learned substantially faster than both the 106$(\mathrm{U}=1, \mathrm{p}<.01)$ and the 130-day-old $(\mathrm{U}=10, \mathrm{p}<.02)$ groups.

In summary, the heat-training procedure revealed a relationship between age and learning speed, insofar as there was a substantial decrement in acquisition rate somewhere between 70 and 106 days of age. Thus, the efficiency of heat training did not obscure this effect, as originally suspected.

\section{REFERENCES}

AGRANOFF, B., DAVIS, R., CASOLA, L., \& LIM, R. Acinomycin D blocks formation of memory of shock-avoidance in goldfish. Science, 1967, 158 , 1600-1601.

BARONDES, S., \& COHEN, H. Memory impairment after subcutaneous injection of acetoxy cy cloheximide. Science, 1968 , $160,556-557$.

D'AMATO, M. R., \& JAGODO, H. Age, sex and rearing conditions as variables in simple brightness conditioning. Journal of Comparative \& Physiological Psychology, 195 y, $53,261-263$.

DENENBERG, V. H. Effects of age and early experience upon conditioning in the C57 3L/10 mouse. Journal of Psychology, 1958, 46, 211-226.

LIU, S. Y. The relation of age to the learning ability of the white rat. Journal of Comparative \& Physiological Psychology, 1928, 8, 75-85.

LO NG, J. A., \& EVANS, H. M. The oestrous cycle in the rat and its associated phenomena. Memoirs of the University of California, 1922, Vol. 6.

MOWRER, O. H., \& LAMOREAUX, R. R. Conditioning and conditionality (discrimination). Psychological Review, $1951,58,196-212$.

WISCHNER, G. J. The effects of punishment on discrimination learning in a non-correction situation. Journal of Experimental Psychology, 1947, 37, 271-284.

YERKES, R. M. Modifiability of behavior in its relation to the age and sex of the dancing mouse. Journal of Comparative Neurology \& Psychology, 1909, 19, 237-271. 